\title{
Decrypting Google's Search Engine Bias Case: Anti-Trust Enforcement in the Digital Age
}

Suyash Bhamore*

\section{Abstract}

For a long time, there has been uncertainty and uneasiness regarding the application of competition law in the digital ecosystem. It is only recently that the evolving Indian competition regime has started facing some of these concerns. In the light of the Competition Commission of India's (CCI) recent encounter with the search-technology giant Google, the paper provides a much needed analysis of the watershed judgment, considering the likely effects it will have on future competition law jurisprudence. CCI has for the first time, by comprehensively analysing the interplay of antitrust laws and tech market, laid down the basic ground work for subsequent cases. The paper begins with probing into the logic and rationale given by CCI in assessing the relevant market, and Google's dominant position in such relevant market. Later, the paper examines if the unique features of digital markets have been incorporated, while analyzing Google's specialized search designs, namely Universal Results, OneBoxes and Commercial Units. Drawing attention to some key concerns like the lack of evidence-based analysis by CCI, the paper concludes by suggesting a suitable remedy and summarizing the key takeaways from the discourse.

Keywords: Abuse of dominance, Antitrust, Competition Commission of India, Digital economy, Google search bias

${ }^{*}$ National Law Institute University, Bhopal, India; suyashbhamore.ug@nliu.ac.in 


\section{Introduction}

Recently, Google's activities have brought it under the scrutiny of thecompetition regulators of various jurisdictions. ${ }^{1}$ Theinformation filed under Section 19(1)(a) of the Competition Act, 2002 (the Act) by Consim Info Private Limited and Consumer Unity and Trust Society, triggered the onset of investigation against Google, by the Indian competition watchdog. The world's largest search engine, Google, has been fined INR 135.86 Crores by the CCI, for abusing its dominant position. ${ }^{2}$ The CCI ruling ${ }^{3}$ is a first of its kind in that it showcases CCI's exchange with a technology giant having considerable influence in the digital space.

The three transgressions for which Google has been held liable are: first, pre-determined display of Universal Results at the first, fourth or tenth position on the Search Engine Results Page (SERP); second, the prominent placement and allocation of disproportionate real estate to the commercial flight unit on SERP4; and thirdly, the restrictive conditions imposed on advertisers through the intermediation agreements. This paper will discuss in detail the concerns surrounding the issue of Google's search engine bias case.

The term 'new economy' is often used to describe sectors of the economy that produce or intensely use new technologies, with an increasing dependence on computers, telecommunications and the Internet. ${ }^{5}$ Big technology companies known for disruptive

1 Geetanjali Sharma, Competition law and E-Commerce: Emerging Trends, Vol. 1 Issue 3, ICLR, 13, 5-15 (2016) http:// www.iclr.in/assets/pdf/ICLR\%20Volume\%201\%20(First\%20Article).pdf.

2 ET Bureau, Google told to pay Rs 135.86 crore fine for abusing its power in India, (New Delhi, Mumbai)(February 09, 2018) https:// economictimes.indiatimes.com/tech/internet/cci-issues-order-againstgoogle-for-search-bias/articleshow/62838992.cms (last accessed on April 04, 2018).

${ }^{3}$ Matrimony.Com Limited vs Google Llc\& Others, CCI, Case Nos. 07 and 30, 2012 (hereinafter Case Nos. 07 and 30 of 2012).

${ }^{4} I d$.

5 Government of Canada, Economic Concepts, Glossary of statistical terms (August 26, 2004) https://stats.oecd.org/glossary/detail.asp?ID=6267 (last accessed on April 02, 2018) 
innovations are not free from acquisition and abuse of market power. ${ }^{6}$ Antitrust assessments of online services and search engines are challenging because of network effects, economies of scale, immense product innovation and fierce competition. Google differs from other information providers as there is no clear benchmark against which to evaluate the quality of the search results it provides. The evolving Indian competition framework has taken a novel approach in addressing the issues concerned with Google's search bias. The paper in the next section illustrates how the Indian antitrust watchdog has cleared the clouds of uncertainty enveloping the administration of competition law,into a New Economy.

\section{The Case against Google}

\subsection{Relevant Market}

\subsubsection{Relevant Product Market}

With regard to the plea of non-applicability of Section 4 to the present case, CCIheld that users offer indirect consideration to Google by providing their eyeballs to the SERP, and allowing Google to collect and use their informationgives the tech giant a huge competitive advantage against most other companies. Both these acts facilitate generation of revenue by Google as it attracts more advertisers. Besides, the revenue earned by search platforms through provision of search based advertisement services negates the view that search services offered by such platforms are free. CCI modeled a neoteric approach in recognizing that assessment of only one of the two sides of Google's business models, would lead to a biased and distorted picture of reality. CCI opined that submissions made by Google were ignorant and missed the role and nature of big data, which in the present case is the aggregate of eyeballs and the choices made by the users. In view of the above,

${ }^{6}$ Smriti Parsheera, Ajay Shah and Avirup Bose, Competition Issues in India's Online Economy, NIPFP Working paper series No. 194, (2017), http://www.nipfp.org.in/media/medialibrary/2017/04/WP_2017_194.p df. (last accessed on April 16, 2018). 
CCI discarded Google's plea and held that online search falls within the ambit of section 4 of the Act.

In taking a view concurring to the Director General's (DG) findings, that online general web search services are not alternative to sitespecific search and specialized search services, CCI relied on factors like variations in terms of characteristics, intended use, price etc. ${ }^{7}$ Also, the CCI found no reason to differ with the analysis of the DG and agreed that online general web search services cannot be substituted with direct search option by typing URL of websites in the internet browsers.

In regard to the issue of search and non-search advertising, CCI noted that search advertising helped advertisers in targeting specific users. Typically, search advertisements are used for demand fulfillment, while non-search advertisements are for brand awareness or recognition. ${ }^{8}$ For this reason, both the advertisements are priced using different pricing mechanisms. In view of the aforesaid, the CCI held online search advertising services to be a distinct relevant product market, in accordance with the provisions of Section 2(s) read with Section 19(7) of the Act. ${ }^{9}$

\subsubsection{Relevant Geographic Market}

CCI's stance was in consonance with the findings of the Office of DG. The Commission reasoned that since CCI is concerned with the market only in India, the relevant geographical market in case of online general web search services were to be limited to India.CCIalso approved the factors considered by the DG, when defining the relevant geographical market. Consequently, it held India to be the relevant geographic market for online search advertising services in accordance with the terms of Section 2(t) read with Section 19(6) of the Act. ${ }^{10}$ As a result, CCI determined the following two relevant markets in the present case for examining the alleged abusive conduct of Google: First, the Market for Online

7§2(t), The Competition Act, 2002, No. 12 of 2003, Acts of Parliament, 2003 (India)

8 Case Nos. 07 and 30 of 2012, para 98.

${ }^{9} I d$. at para 94 .

${ }^{10} I d$. at para 100. 
General Web Search Services in India and second, the Market for Online Search Advertising Services in India.

\subsubsection{Analysis}

The manner in which the relevant market is determined decides whether the companies ultimately face antitrust liability or not.11 CCI has aptly taken into its purview the unique features of digital markets, when determining the relevant market. This is believed to be true because, CCI in this judgment deviated from its antagonistic approach of holding online platforms and the off-line traditional brokers, as part of the same relevant market. ${ }^{12}$ Such an approach was endorsed by the CCI in a case filed by the Real Estate Brokers' Association of India against online platforms like Magicbricks, 99acres and Housing.com. ${ }^{13}$ CCI, in holding online and offline markets as separate, has provided important perspective.

Furthermore, the relevant market definition for Internet-based businesses is dependent on an assessment of whether brick-andmortar substitutes are available for the given product or service. ${ }^{14}$ However, digital markets make it exhausting to outline the relevant market, because the product or service being dealt with by internet businesses is 'information' and not some corporeal commodity. CCI has adopted the principle of relying on the geographic locations of the individuals using Internet to define the geographic market. ${ }^{15}$ Hence, the CCI has embraced a visionary approach fordefining markets in a way that captures the probable effects of competition.

11See Tanaka v. Univ. of S. Cal., 252 F.3d 1059, 1063 (9th Cir. 2001) ("Failure to identify a relevant market is a proper ground for dismissing a [monopolization] claim.").

${ }^{12}$ Ashish Ahuja v. Snapdeal.com, Case No. 17, 2014,CCI; See also Mr. Deepak Verma v. Clues Network Pvt. Ltd, CCI, Case No. 34, 2016.

13 Confederation of Real Estate Brokers' Association of India v. Magicbricks.com and others, Case No. 23, 2016, CCI at para 11.

14Supra note 9.

15 Am. Online, Inc. v. GreatDeals.Net, 49 F. Supp. 2d 851, 858 (E.D. Va. 1999) (quoting Cyber Promotions, Inc. v. Am. Online, Inc., 948 F. Supp. 456, 459 (E.D. Pa. 1996)). 


\subsection{Assessment of Dominance: An Analysis}

How one determines whether and to what extent market power exists in particular circumstances is an important issue. ${ }^{16}$ By virtue of explanation (a) to Section 4 of the Act, 'dominant position' means a position of strength enjoyed by an enterprise in the relevant market, which enables it to operate independently of competitive forces.In the new economy, neither the market share is sufficient in itself to dictate dominance ${ }^{17}$, nor can the threshold be wisely fixed to establish dominance. The Commission relied on the empirical data submitted by the DG in this regard. This comprised of Google's significantly high market share in the sphere of online general web search in India, as well as on global basis. The Commission also acceded to take into consideration Google's revenue earned by the AdWords (services used by advertisers for online promotion of their content, brand, and website ${ }^{18}$ ) and AdSense programs in the relevant market, while deciding upon Google's dominance. ${ }^{19}$ It observed that the significant barriers to entry and Google's scale benefit reinforced the effect of Google's high market shares in establishing Google's dominance in the online general web search and search advertising markets. ${ }^{20}$ The Commission recognized that in seeking to understand whether Google is dominant in the relevant market or not, the question that should be addressed is whether Google would lose market share materially, if it were to reduce innovation. This was answered in the negative, for the reason that it was highly unlikely that a large number of users would switch to a competing search engine in a

16 Michal S GAL, Competition Policy for Small Market Economies, Harvard University Press (2009).

17 Dominance does not exist in the abstract, but in relation to a particular market. See Case 6/72 Continental Can v. Commission; See also United Brands v. Commission, European Court Reports 1978 -00207; L'Oréal v. PVBA De Nieuwe, Case 31/80 [1980] ECR 3775, [1981] 2 CMLR 235.

18Business News: Analytics, Definition of 'AdWords', https://economictimes.indiatimes.com/definition/adwords (last Accessed on 02 December, 2018).

${ }^{19}$ Case Nos. 07 and 30 of 2012 at para 115.

${ }^{20} I d$. at para 117 . 
short or medium term, even if Google reduced the quality and innovation of its services.

CCI rejected Google's claim of Facebook posing threat to Google's position, as an upcoming competitor in the online advertising market. As the relevant market for Google includes online search advertising services only, Facebook and other entities engaged in non-search and display advertising, were not Google's competitors in the search advertising market. CCI also recognized Google's significant head start in crawling and indexing of data, which gave Google aninsurmountable scale advantage. As only market participants in the online general web search market can compete in the search advertising market, the barriers in the online general web search market also effectively restrict entry into the search advertising market.In multi sided high technology markets, innovation is the key and market shares therefore should be transient. Due to disruptive cycles of innovation, last year's winner could quickly become this year's nobody. However, Google's consistently high market shares suggested, that it has got other advantages, besides technical advantages, which insulate its market position. In view of this, the Commission had no hesitation in holding that Google was dominant in both the relevant markets.

Antitrust issues in digital frameworks require special focus on the dynamic effects that come up when assessing cyber entities. These dynamic effects may include changes in quality, innovation and efficiency.21 Identifying factors other than market share in ascertaining Google's position, underlines the prudent and foresighted outlook adopted by the Commission. Google's role as the gatekeeper of the information on internet, to majority of the users in India, weakens Google's case.22 Moreover since revenue

21 Dr. Maria Maher, Paul Reynolds, Paul Muysert and Dr. Fred Wandschneider, Executive Summary, Resetting competition policy frameworks for the digital ecosystem , (October 2016), https://www.gsma.com/publicpolicy/wpcontent/uploads/2016/10/GSMA_Resetting-Competition_Report_Oct2016_60pp_WEBv2.pdf.

${ }^{22}$ See Robert H. Bork, Antitrust and Google, CHI. TRIB. 1, (Apr. 6, 2012), at 19, http://artictes.chicagotribune.comV2012-04-06/news/ct-perspec-0405bork-20120406-1 unpaidsearch-results-search-engines-search-algorithms. 
from advertising, whichis the lifeblood of most web pages, is tied to a website's traffic, Google is in a position to decide whose content flourishes and whose flounders. ${ }^{23}$ Going by the number of competitors to determine dominance, Google faces opposition from just two other search engines- Bing and Yahoo. ${ }^{24} \mathrm{CCI}$ has exhibited the much required technological acumen in its assessment of the case.

Google's defenders argue that competition is just one click away and people have full liberty to explore search engines other than Google, but they forget that most people believe the first item they see as the most relevant listing. Relevance is a slippery and subjective concept and it is not the same for every person. ${ }^{25}$ The source of Google's power lies in the inability of those who engage in searches, to evaluate the relevancy of search results. This is due to the trust reposed by them in Google's ability to sort the most relevant content. This led CCI to hold Google as a dominant entity in the concerned market.

The reasons laid down by $\mathrm{CCI}$ in declaring Google as dominant are strikingly similar, to the line of reasoning endorsed by the European Union (EU) in the famous Google Comparison Shopping decision. The European Commission (EC) had concluded Google to be dominant across the whole European Economic Area, owing to its consistently high market share, barriers to entry and the deleterious network effects. ${ }^{26}$ Furthermore, Google's standing as a

${ }^{23}$ See Google Senate Antitrust Subcommittee Hearing 3, (Statement of Sen. Michael S. Lee, "Given its dominant position, most internet-based businesses rely on Google for a substantial share of their traffic in revenues.").

${ }^{24}$ SeeCarolanne Mangles, Search Engine Statistics 2018, (Jan. 30, 2018), https:// www.smartinsights.com/search-engine-marketing/searchengine-statistics/ (last accessed on April 13, 2018).

${ }^{25}$ See Geoffrey A. Manne and Joshua D. Wright, If Search Neutrality Is the Answer What's the Question? 7 Int'l Ctr. for Law \& Economics White Paper Series, (2011) https://laweconcenter.org/ images/ articles/ search_neutrality_manne_wright_final.pdf.

26 European Commission - Press release, Antitrust: Commission fines Google $€ 2.42$ billion for abusing dominance as search engine by giving illegal advantage to own comparison shopping service, (June 27, 2017) 
dominant entity has been cemented in the Google-Android operating system case, wherein the entity was pronounced to be dominant in the markets for general internet search services, licensable smart mobile operating systems and app stores for the Android mobile operating system. ${ }^{27}$ Third in the series is Google AdSense Advertising case, which is expected to be conclusively determined and rolled out in 2019. In its preliminary statement of objections to Google, the EC has determined Google to be a dominant enterprise, again, due to its unfailingly high market share. ${ }^{28}$

The preceding trilogy of cases underlines how the EU has handled the issue of ascertaining the dominance of enterprises thriving in digital markets. It is believed thatthe outlook of CCI may have been impracticable and stretched over and beyond conventional determinants of assessing dominance, such as the market share of enterprises, while maintaining conformity with the leading competition jurisdictions.

\subsection{Search Bias}

Having perused the DG's findings and Google's submissions, CCI went on to examine if the specific allegations made against Google concerning its abuse of dominance hold up or not.

\subsubsection{Universal Results}

Universal Results refers to the blending of additional media for a specific type of information, such as news and images, with the organic results for an enhanced search experience.The contention of Google that 'its systems were not sufficiently advanced to conduct

http://europa.eu/rapid/press-release_IP-17-1784_en.htm. (last accessed on April 09, 2018).

${ }^{27}$ European Commission - Press release, Antitrust: Commission fines Google $€ 4.34$ billion for illegal practices regarding Android mobile devices to strengthen dominance of Google's search engine, (July 20, 2018)

28 European Commission - Press release: Antitrust: Commission takes further steps in investigations alleging Google's comparison shopping and advertising-related practices breach EU rules, (July 21, 2018) 
a relevance comparison for all positions on the result page ${ }^{29}$ was disallowed by CCI in the absence of concrete material to support it. Moreover, Google gave no satisfactory reasons for limiting the display of Universal Results to the fixed positions. The Commission found that rankings of Universal Results prior to 2010 were not strictly determined by relevance, but instead were pre-determined. CCI held that the practice of displaying Universal Results on fixed positions was unfair, as it created a misleading façade that such search results were appearing based on their relevance. This was held to be a violation of Section (4)(2)(a)(i) of the Act.

\subsubsection{OneBoxes}

OneBox is a specially delineated box which appears within Universal Results, highlighting news, images and videos. The intent behind displaying OneBox is to give the user information directly from Google, without having to move to any other site. CCI observed that OneBoxes provide short factual answers to the user's query. Queries relating to mathematics, stock quotes, local time, currency conversion, and weather, have one possible answer, which OneBox provides. The CCI found DG's observation of there being bias in the sources that Google selects for OneBoxes' content, not backed by evidence. Mere possibility that it may not select the most relevant provider, is not a substitute for actual evidence of bias. DG's concern that Google's OneBoxes do not select the most relevant answer is mistaken because,OneBoxes respond to queries for which there is only one canonical or factual answer. In that case, the question does not arise as to which content provider gave the most relevant answer.Furthermore, the fact that Google receives no payment from the content providers for showcasing their content on OneBoxes, gives Google no reason to choose an inferior source of information. Google has also pointed out that it monitors and evaluates the content providers on an ongoing basis, to decide whether to renew a content agreement with the same provider or select a different provider. Further, no evidence of Google selecting an inferior information provider was presented by the DG. All things considered, $\mathrm{CCI}$ declared the conclusions drawn by the DG qua OneBox, as not made out.

${ }^{29}$ Case Nos. 07 and 30 of 2012 at para 30. 


\subsubsection{Commercial Units}

Commercial Units are search results that Google sets apart in ad space, with a label indicating them as 'Sponsored'. CCI found that Google allotted a disproportionately high estate to sponsored results on SERP. This prominent placement of Commercial Units served two purposes- it allowed Google to steer people to its own pages and not to third party websites and the conspicuous positioning of Google Flights page above the ten blue links, helped Google gain advertisement revenue, by denying the key real estate to third party verticals. Therefore, CCI found that such partisan division of traffic by Google, pushed competing verticals down and out of user's eyesight.

CCI held that Google's public claim of ranking results based on relevance had a huge impact on clicking behavior of users. CCI even highlighted excerpts from, first, Google's 2004 Initial Public Offerings with the U.S. Securities and Exchange Commission, where Google made the statement, "We will do our best to provide the most relevant and useful search results possible, independent of financial incentives. Our search results will be objective and we will not accept payment for inclusion or ranking in them $30^{\prime \prime}$, second, the letter accompanying the IPO filing made by Google's founders where they stated "Our search results are the best we know how to produce. They are unbiased and objective, and we do not accept payment for them or for inclusion or more frequent updating. $31^{1 "}$, and third, Google's Executive Chairman, Eric Schmidt's statements "the natural search answers [are] completely unbiased with respect to economics." ${ }^{32}$ In all three above mentioned instances, Google

30 Google's registration statement filed with the Securities and Exchange Commission, Prospectus summary, (August 18, 2004) https://www.sec.gov/Archives/edgar/data/1288776/0001193125041433 77/d424b4.htm (last accessed on April 05, 2018).

${ }^{31}$ Google's registration statement filed with the Securities and Exchange Commission, Letter from the Founders "An Owner's Manual" for Google's Shareholders, (August 18, 2004) https://www.sec.gov/Archives/edgar/data/1288776/0001193125041433 77/d424b4.htm (last accessed on April 05, 2018).

32 National Public Radio, CEO: Google Knows A Lot About You, Then Forgets, (October 02, 2009) https://www.npr.org/ 2009/ 10/ 02/ 
had publicly claimed that its results are "unbiased and objective". These public pronouncements have a huge impact on user's clicking behavior. Hence, the users were deceived and misled whenever Google treated Commercial Units in a preferential and biased manner.

The Commission also observed that such prominent placement of commercial units on SERP could give rise to yet another anti-trust concern. Luring consumers to search for more flights on the Google Flight page, allowed Google to collect more user data to reinforce its advantage in search advertising market. The user data that Google was able to collect did not allow other competing vertical search pages the same benefit and deteriorated their ability to further innovate on their products. Thus, CCI found it impossible to deny that Google was leveraging its dominant position in General Web Search, to provide gateway for users to find relevant travel verticals. The crux of the matter lies in the reduced visibility given to equally efficient websites, due to which they are unable to sustain and survive in the market for flight search services. The Commission had no hesitation in holding that Google, through its search design, had not only placed its commercial units right at a prominent position on SERP, but had also allocated disproportionate real estate thereof to those units resulting into pushing down or pushing out of the verticals, who were attempting to gain market access. This conduct of Google, which is an unfair imposition upon the users of general search services, is in contravention of Section 4(2)(a)(i) of the Act. ${ }^{33}$

\subsubsection{Analysis}

CCI displayed a pro-innovation stance in recognizing product design as an integral dimension of competition. The majority view showcased adoption of a stringent and bold approach in holding Google, in violation of law, for an act which had been remedied by Google, approximately two years prior to the date of filing of information. The dissenting judges endorsed a different rationale for their stand. Concerning Universal Results, it was opined that

113450803/ceo-google-knows-a-lot-about-you-then-forgets (last accessed on April 05, 2018).

33 Case Nos. 07 and 30 of 2012 at para 253. 
the changes in the system brought about by Google post 2010 obviate the need for any regulatory intervention, especially when the new fully-floating regime appropriately addresses the concern. ${ }^{34}$ They stated that persecution of Google with respect to its historic use of fixed positions for Universal Results on SERP, was uncalled for. However, this standpoint is susceptible to criticism, because it ignores the 'special responsibility' that Google as a dominant enterprise in the digital space, is bound to abide by. This unfavorable decision comes as a reminder to all dominant entities, of their fallibility. Super dominant firms like Google are not expected to take unfair advantage of their position, as such abusive conduct, not only impacts the market as a whole, but may also affect the entry and sustenance of other market participants into complementary markets.

Attending to the issue of display of Commercial Units at a prominent place on SERP, the minority view was of the opinion that penalizing an enterprise on account ofhypotheticalframeworks built on perceived premises would be inappropriate and unseemly. The lack of statistical data to support findings against Google was highly instrumental with the dissent of two minority judges. Although the findings made by the DG may prima facie persuade one into believing in Google's indulgence in abuse of its dominant position, such findings, in the absence of robust data and evidence remain mere conjectures. Allegations need the backing of empirical data, before they materialize into a water tight case.

Understanding European Union's approach in dealing with Google, will allow us to have a better perspective in this regard. In imposing a fine on Google, EU had collected and extensively evaluated a large bundle of evidence ${ }^{35}$, includinga) significant quantities of real-world data including 5.2 Terabytes of actual search results from Google (around 1.7 billion search queries). ${ }^{36} \mathrm{~b}$ )

34 Dissent Note dated 08.02.2018 in Case Nos. 07 and 30 of 2012 at para 31.

35 European Commission - Press release, Antitrust: Commission fines Google $€ 2.42$ billion for abusing dominance as search engine by giving illegal advantage to own comparison shopping service, (June 27, 2017) http:/ / europa.eu/rapid/press-release_IP-17-1784_en.htm. (last accessed on April 09, 2018).

36Id. 
experiments and surveys, analyzing in particular the impact of visibility in search results on consumer behaviour and clickthrough rates. ${ }^{37} \mathrm{c}$ ) a comprehensive analysis of questionnaires which EU had addressed to several hundred companies. ${ }^{38}$

The aforementioned facts indicate the substantial reliance of the European competition framework on statistical data, when investigating potential violations of the law. The dissenting opinion running on similar lines show contempt for penalizing Google in the absence of sufficient data. The author is of the opinion that in such a case, directing the DG to conduct further investigation or pursuing an inquiry on its own ${ }^{39}$, would have been the better choice.

Moving to an economic forefront, the probe into Google and its mechanics brings to light, the glaring dissimilarities between the argumentation followed by the Indian Competition Commission and the United States' Federal Trade Commission (US FTC). US FTC, to an extent, untangled the conundrum surrounding the interface of competition with technology, in the Matter of Google Inc. ${ }^{40}$ Contrary to the findings made by CCI, FTC came out with a finding favourable for Google and absolved it from liability, subject to monitoring of the actions of Google. It is amply clear from the language used by the FTC that the favourable order stemmed from its extensive reliance on the Chicago school of thought. The Chicago school emulates that the primary goal of competition law is the betterment and advancement of the consumers, irrespective of the actions undertaken being anticompetitive. A cursory perusal of the order by FTC will divulge that the bench considered

${ }^{37} I d$.

${ }^{38} I d$.

${ }^{39} \S 26(7)$, The Competition Act, 2002, Act No. 12 of 2003, Acts of Parliament, 2002 (India).

40 Statement of the Federal Trade Commission Regarding Google's Search Practices, (January 03, 2013) https://www.ftc.gov/ sites/ default/ files/documents/public_statements/statement-commission-regardinggoogles-search-practices/130103brillgooglesearchstmt.pdf (last accessed on June 08,2018 ) 
Google's biased results 'as an improvement in the overall quality of Google's search product'. ${ }^{41}$

On the other end of the spectrum, lies the Harvard school of thought, which has the countenance of both the CCI and the EC. The Harvard school dictates that all anticompetitive activities are inherently presumed to be illegal heedless of the alleviating effects of such activities on consumers. As is evident from the concerned rulings, the import of Chicago school is discounted in favour of the competition oriented Harvard school of thought. This is because, in spite of appreciating the benefits incurring from Google's biased results, the entity was heavily penalized for stifling competition.

\section{Possible Remedies}

\subsection{Need for Intervention}

There has been much dialogue relating to the upcoming role of competition authorities in ensuring that the internet based businesses function within a competitive framework. Typically, there are two factions endorsing their respective views regarding the optimal competition policy.

\section{i. The Schumpeterian Idea of Creative Destruction}

Joseph Schumpeter, professor at Harvard University, coined the term 'creative destruction' 42 . One of the most influential economists of the 20th Century, Schumpeter propounded that there is tremendous possibility of a periodic paradigm shift in internet economies, which do not allow a once dominant business to maintain its preeminence for a long period. In the era of New Economy, there is constant fear of being overthrown by a new innovation, due to rapid technological changes. Such a scenario does not call for government intervention because the tempo at which decisions are made by competition authorities and the technical know-how at hand, is not sufficient to assess the

41 Id.

42 J.A. Schumpeter, Capitalism, socialism, and democracy, 3 New York: Harper Perennial (1950). 
competition issues in these avant-garde fast-moving sectors. ${ }^{43}$ The incongruence between law time - time taken by authorities in deciding a case, and internet time, results in the findings to become extraneous. ${ }^{44}$ Superfluous intervention may even harm the users as well as the competition by chilling innovation.

\section{ii. Traditional Assessment}

The traditional or conventional view of competition assessment is the most commonly adopted framework by any competition authority. When looking at New Economy, features like economies of scale, network effects and the possibility of consumers being locked-into a particular network become the exigent factors to be paid heed to, for active competition enforcement. In general, this approach involves the identification of the relevant market, establishing whether the firm in question is a dominant player in that market, and then an assessment of whether there has been an abuse of dominance.

\subsection{A Viable Remedy}

If the existence of such a bias by any search service provider could be proven, finding an adequate remedy that does not affect the competitive structure of the industry is challenging. While commitment made by search engines not to engage in search bias may help maintain the status quo, augmented interventionist measures such as watching over generation of search results with a view to ensure objectivity, may well reduce their quality. ${ }^{45} \mathrm{~A}$ plethora of remedial measures such as search neutrality, doing away with Universal Results, and continuous disclosure of changes made to the algorithms, have been suggested by numerous

\footnotetext{
43 Supra note 5.

${ }^{44}$ Avirup Bose and Smriti Parsheera, Network Effects in India's Online Businesses: A Competition Law Analysis, (Sept 30, 2016), http:/ / www.cresse.info/uploadfiles/2017_pa14_pa2.pdf.

${ }^{45}$ DikerVanberg, A, 'From Archie to Google -Search engine providers and emergent challenges in relation to EU competition law', 3 EJLT (2012), http:/ / ejlt.org/article/view/115/198.
} 
academicians to redress the situation. Nevertheless, each suggested remedy suffers from some lacunae. This warrants for a search of an alternative remedy like commitments made by accused parties to resolve issues quickly and efficiently.

\subsubsection{Search Neutrality as remedy}

This remedy requires Google to use 'neutral' search algorithms and display search results in an 'even-handed' manner. ${ }^{46}$ In view of the transition from ten blue links model, to a model where ultimate information sought itself is displayed, search neutrality as a principle is incongruous. Further, the employment of search neutrality solely by Google, owing to its dominance in the market, is irrational. Such an application of search neutrality will handicap Google from investing in further research and development of search engines. Furthermore, it is contrary to the very idea of search engines which is to 'discriminate'between the results, to provide a list of the most relevant sites. ${ }^{4}$ Thus, the future of search neutrality as a broad principle that produces search result rankings based on some 'unbiased' metric of relevance, ${ }^{48}$ is both impractical and unattainable.

\subsubsection{Ten blue links, as opposed touniversal search as remedy}

Another alternative suggested to protect competition in digital economy was to forbid Google from incorporating Universal Results, along with the organic results. This would essentially mean Google reverting back to its decade old arrangement of displaying ten blue links. This will alleviate Google's competitors, but separating general and specialized search will come at the

\footnotetext{
46 Marvin Ammori and Luke Pelican, Why Search Bias Claims Against Google Don't Hold Up, (June 7, 2012), https://www.forbes.com/sites/ciocentral/2012/06/07/why-search-biasclaims-against-google-dont-hold-up/\#eb5ac06f7faa.

${ }^{47} I d$.

${ }^{48}$ See Eric Goldman, Search Engine Bias and the Demise of Search Engine Utopianism, 8 YALE

$\begin{array}{lllll}\text { J.L. } \& & \text { TECH. } & 189 & \text { (2006). }\end{array}$ https:/ / digitalcommons.law.scu.edu/cgi/viewcontent.cgi?referer=https: / / www.google.co.in/\&httpsredir=1\&article=1112\&context=facpubs.
} 
expense of general search users. Consumers undoubtedly prefer integrated search results. Even Google's competitors like Bing, assimilate specialized search results with the general search results. Hence, the author dismisses it as a non feasible measure.

\subsubsection{Continuous disclosure as remedy}

This category of remedy requires Google to reveal every minor change they make in their search algorithms. It is unfair to seek the aforementioned, from a company whose primary business operates on these very algorithms. If implemented, this would result in a clear case of overreaching transparency requirement. Google, by releasing transparency reports ${ }^{49}$ already does justice in regard to transparency, and coercion to further disclose all the minor adjustments made, will be similar to encouraging spamming, resulting in frustrated consumers. The impracticality of the aforementioned remedies removes them from the scope of implementation. This necessitates the need for a solution, which will efficaciously address the problems posed by search engine bias. The next part of the paper comprises of a discourse on the scope of 'commitments or settlement' as an effective remedy in the New Economy, with the Indian landscape being the focal point of discussion.

\subsubsection{Analysis}

Remedies such as search neutrality and continuous disclosure, threaten competition as well as consumer welfare, by impeding innovation, merely to benefit the competitors of Google. This is a case of competitors concocting to alleviate themselves, by weakening Google as a competitor and harming consumers and competition as a result. ${ }^{50}$ Equitable remedies for monopolization have three goals: to terminate a defendant's unlawful conduct, to prevent that conduct's recurrence, and to re-establish the opportunity for competition. ${ }^{51}$ The challenge lies in selecting a remedy that furthers these goals 'without imposing undue costs on

49 Google Transparency Report, https://transparencyreport.google.com/ (last accessed on April 18, 2018).

${ }^{50} I d$.

51 United States v. Microsoft Corp., 253 F.3d 34, 103 (D.C. Cir. 2001). * 
the court or the parties, without unnecessarily chilling legitimate competition, and without undermining incentives to invest and innovate ${ }^{52}$.

Competition authorities need to resolve the matters expeditiously. The Supreme Court of India very well realized the importance of time factor when it stated "In the event of delay, the very purpose and object of the Act is likely to be frustrated and the possibility of great damage to the open market and resultantly, country's economy cannot be ruled out." 53 Internet businesses expand and flourish at a pace faster than traditional sectors. In order to make an impact, authorities have a small frame of time before network effects set in. This warrants for the urgent requirement of a robust and time bound system by antitrust authorities that can ensure that their findings remain relevant in the light of the fast moving markets. By the time the Commission reaches a concluding remark, the company in question may already have lost its dominant position, or the complainant may no longer exist. Further, owing to the intricate nature of the search industry from a technological viewpoint, the Commission requires complex technical analysis from industry specialists, which inflate the period and cost of proceedings.

The length and controversial nature of the Microsoft cases in the USA, involving a series of investigations concerning the issue of monopolization of market for personal computer operating systems, and the EU, concerning the abuse of dominant position, by Microsoft, as a supplier of operating systems for personal computers, affirm this position and opens a discourse for

\footnotetext{
52 US Department of Justice, Competition and Monopoly: Single-firm Conduct Under Section 2 of the Sherman Act (September, 2008), https:// www.justice.gov/atr/competition-and-monopoly-single-firm-conductunder-section-2-sherman-act (last accessed on April 20, 2018).

53 Competition Commission Of India vs Steel Authority Of India \&Anr, (2010) Comp LR 0061; See also Namrata Marketing Pvt. Ltd. vs Competition Commission Of India, Civil Misc. Writ Petition No. 42783 of 2013.
} 
alternative approaches in dealing with competition problems in high tech markets. ${ }^{54}$

In this regard, the suggested scheme is that of accepting commitment decisions from firms and businesses that are under antitrust scrutiny, or have been found to be engaging in illicit practices. Commitments can help achieve effective and expeditious relief from anticompetitive conduct, without both the authority and the party incurring costs of delay and litigation. Such a mechanism is already in operation by the European Commission (EC) and FTC (Federal Trade Commission).EC has a practice of accepting commitments from firms without the need of a full-fledged investigation. ${ }^{55}$ Likewise, FTC and the Department of Justice accept consent agreements. These settlements have halted unlawful conduct and prevented their recurrence in many matters, over the decades, in the U.S. ${ }^{6}$ Moreover, commitments are legally binding and attract penalty in case of violation.

In the context of wide use of commitments and settlements as remedial mechanisms, India is yet to recognize commitments as part of the antitrust enforcement matrix. Tamil Nadu Film Exhibitors Association v. CCI $\mathcal{E}$ Ors. ${ }^{57}$ clarified that the discretion given to CCI allows it to accept settlements as appropriate remedy for anticompetitive conduct. ${ }^{58}$ The Madras High Court addressed the issue as to whether two adversaries could reach a settlement between themselves and thereby preclude the investigation initiated by CCI. It was ruled that settling disputes by commitments was within the scope of the Act, owing to the residuary powers vested with $\mathrm{CCI}$ to pass such orders or issue

${ }^{54}$ See Richard A. Posner, 'Antitrust in the New Economy' John M. Olin Program in Law and Economics Working Paper No. 106, 9 (2000).

${ }^{55}$ Antitrust Regulation 1/2003, Article 9(1).

56 Directorate for Financial and Enterprise Affairs Competition Committee, Commitment Decisions in Antitrust Cases -Note by United States (June 02, 2016), https:/ / www.justice.gov/atr/file/873491/download (last accessed on April 17, 2018)

${ }^{57}$ M/S. Crown Theatre vs Kerala Film Exhibitors, Case No. 16 of 2014. $58 \S 27(\mathrm{~g})$, The Competition Act, 2002, Act No. 12 of 2003, Acts of Parliament, 2002 (India) 
directions as it may deem fit..$^{59}$ The judgment went on to rule three pre-conditions that CCI must be satisfied of, before accepting any commitment. First, such a settlement should not lead to continuance of anti-competitive practices, second, it should not allow an abuse of dominance to continue and third, it should not be prejudiced to consumer interests of freedom of trade. This judgment is commendable with regard to the masses privy to the Indian competition landscape.

\section{Conclusion}

The CCI ruling on Google will have a series of effects on the development of Competition law in India. The present paper has summarized the position taken by $\mathrm{CCI}$ in tackling the digital economy's elemental features, when confronting a technology giant. The impact of network effects, technology lock-in and the speed with which a dominant player can take control of a sector, call for earlier regulatory intervention in technology markets. 60 Relying on ex post facto and drawn out court battles, is not the approach to be adopted when regulating New Economy. Schumpeterian ideology of non-intervention surmises the presence of budding innovative startups, waiting to overhaul the market. However, in reality, people today are innovating solely with the aim of being acquired by existing major market players, as a cashout option. Selling one's smaller company to established big firms, rather than competing as independent companies, has become prevalent. Dethroning incumbents in technology markets is trickier and more complex than in traditional markets. Hence, the need of the hour is an ahead of time ex-ante intervention by regulators to displace a powerful company like Google. This necessitates, the paper argues, the need for CCI to nip in the bud, the businesses that are on the path to imminent dominance. Therefore, the CCI's role should not be limited to an ex-post facto scrutiny of abuse of dominance. Competition standards for the new economy should,

${ }^{59} I d$.

${ }^{60}$ See Jonathan Zittrain, The Un-Microsoft Un-Remedy: Law Can Prevent the Problem that It Can't Patch Later, 31 CONN. L. REV. 1361, 1361-62 (1999). 
instead, allow the CCI to prevent the harm, before it is done, by including a standard to review the abusive market conduct of firms, which are in a position of imminent dominance. If not, the result will be akin to the ingrained hegemony that Google was able to establish, while antitrust overseers lay passive. Therefore, the researcher suggests a shift in approach toexamining the means through which a firm sets 'on the path of imminent dominance'. In other words, the author recommends to fix the threshold at 'abuse to dominate' instead of 'abuse of dominance' for penalizing enterprises which resort to anti-competitive conduct to gain a dominant position in digital market.

Regarding the fate of commitments or settlement as mechanisms of resolving antitrust issues, the High Court ruling has a coming-ofage effect on Indian Competition schema. However, the fact that the High Court decision dealt with 'inter-party settlement' i.e. settlement between the informant and the alleged party, must be accounted for, before venturing ahead with this proposal. The Court was silent as far as the issue of 'commitments being made to $\mathrm{CCI}^{\prime}$ is concerned. Additionally, the wide discretion given to CCI under Section 27 comes into play, when CCI has arrived at a finding of contravention. Whether CCI can accept a settlement at a stage where it has not yet reached a finding of contravention is unclear. The paper encourages adoption of a voluntary settlement scheme that will allow a business that is under investigation to voluntarily alter its market behavior, without the need for a conclusive finding of violation by the CCI.

The CCI judgment has been well received by Indian vertical search engines. CCI has exhibited utmost awareness in departing from the traditional approach of evaluating markets and applying a nuanced approach to competition law's interaction with digital economy. The judgment resonates a sense of sound competition policy for ongoing competition, investment and innovation that will benefit all players. The author is of the opinion that CCI has stricken a balance between too rigid an antitrust policy and an excessively liberal antitrust policy. Further, the CCI's approach highlights its confidence, and indigenous attitude in dealing with innovative technology markets. The Indian competition regime is constantly evolving and has only recently begunto face unconventional 
concerns such as the one presented in the paper. The methods employed by CCI havesufficiently addressed the Google conundrum and instilled a sense of confidence in the concerned populace regarding the future of the Indian competition regime. 